\title{
Optimising clinical practice to support a sustainable NHS
}

Welcome to the June edition of Clinical Medicine. As you may recall the president challenged me, in this our 500th year, to use the academic journals to focus on key areas in healthcare that cut across both clinical and non-clinical domains, and that raise key issues that affect both our working lives and the lives of our patients. After exploring end-of-life care issues in February, we now turn our attention to sustainability. Alongside detailed articles on how to incorporate and value sustainable initiatives in quality healthcare initiatives within Future Healthcare Journal, in this edition of Clin Med we look at sustainability from a more clinical perspective, alongside the usual offerings of research, NICE updates, CME articles, clinical lessons and images.

Unsurprisingly, given the current austerity agenda being brought to bear on the public sector, most of us in the NHS focus on the financial aspects of the sustainability of the NHS, as I did in my last editorial. It remains to be seen whether the apparent cross-party support for a dedicated tax to support the NHS gains traction, but the predictions from Lord Darzi's latest report on the financial requirement to sustain the NHS do not make for optimistic reading ${ }^{1}$ and suggest we need to move quickly to head off a generation of funding crises.

However, sustainable healthcare encompasses, and requires attention to, so much more than the money. The locations in which we choose to deliver healthcare, the way we procure our drugs and equipment, the way we choose to manage our patients and the way we dispose of our waste all contribute to how sustainable our healthcare system is. As I outline in my editorial in FHJ, sustainability is about efficiency, effectiveness, economics and the environment. ${ }^{2}$ As just one example, the NHS is a major contributor to $\mathrm{CO}_{2}$ and other greenhouse gas emissions in the UK. The pollutants that arise as a direct consequence of over a million NHS staff driving to and from work, our patients attending hospitals for their routine or emergency care, the journeys made by their carers and visitors, our supply chain providing the material we need to deliver healthcare, and the way we dispose of our clinical waste, all contribute to the environment in a harmful and negative way.

To minimise this, initiatives to reduce length of stay, while clearly of clinical benefit to our patients, and cost effective, also help to minimise these additional environmental concerns. Initiatives to reduce unnecessary clinical activity, such as outlined by Woodford, ${ }^{3}$ can clearly be seen to demonstrate savings from reduced testing, but looked through a prism that incorporates a wider sustainability perspective also reduce the need for assays to be not just procured but delivered, and attendance for follow-up to deal with the inevitable uncertainty that a (true or false) positive result might bring. The use of alternative, non-pharmacological interventions, such as outlined in Thompson's thought-provoking article on gardening for health, also highlights the wider societal, cultural and environmental benefits of a sustainable health model that potentially addresses wellness, disease prevention and societal cohesion, as well as illness management. ${ }^{4}$

Valuing and managing the workforce is also critical to a sustainable NHS and the longstanding reality that current immigration policies can prevent willing and able clinicians from coming from abroad to support the NHS is finally making headlines the mainstream media. The risks of Brexit and the ramifications of the Windrush scandal and hostile immigration policies further add to the already challenging workforce crisis that exists in the NHS. The RCP, along with our sister colleges, has been highlighting and lobbying on these issues for many months. Without a sustainable, engaged and valued workforce the future of the NHS cannot be secure.

So, I hope that you enjoy this edition of Clin Med and our focus on sustainability, and that we continue to provide you with digestible, practical and interesting articles that support your clinical practice.

\section{References}

1 Institute for Public Policy Research. The Lord Darzi Review of Health and Care: Interim report. IPPR, 2018. www.ippr.org/publications/ darzi-review-interim-report [Accessed 9 May 2018].

2 Nicol E. Sustainability in healthcare: efficiency, effectiveness, economics and the environment. Future Health care J 2018;5:81.

3 Woodford HJ, Barrett S, Pattman S. Vitamin D: too much testing and treating? Clin Med 2018;18:196-200.

4 Thompson R. Gardening for health: a regular dose of gardening. Clin Med 2018;18:201-5.

Wing Commander Ed Nicol Editor-in-chief

$\begin{array}{ll}\text { Members of the editorial board } & \\ \text { Wing Commander Edward Nicol } & \text { Prof Tahseen Chowdhury } \\ \text { Editor-in-chief } & \text { Dr Nick Cork } \\ \text { Cono Ariti } & \text { Dr Albert Edwards } \\ \text { Statistical editor } & \text { Dr Kate Evans } \\ \text { Dr Na'eem Ahmed } & \text { Dr Johanna Feary } \\ \text { Dr Michael Almond } & \text { Dr Maggie Hammersley } \\ \text { Mr Paul Belcher } & \text { Dr Dylan Harris } \\ \text { Prof Rodger Charlton } & \text { Prof Brian Hurwitz } \\ \text { Dr Tim Chevassut } & \text { Dr Nicola Jones } \\ \end{array}$

Dr Alexandra Lake Dr Tom Levett Prof Philip MacCarthy Prof Yash Mahida Dr Chris Marguerie Dr Ravik Mascarenhas Prof Martin McKee Dr Andrew Medford Dr Rahul Mukherjee Dr Nicola Lomax
Dr Mehool Patel Dr Gerrard Phillips Dr Roby Rakhit Prof Phil Smith Dr Angela Star Prof Cameron Swift Dr Rhys Thomas Dr Duncan Wilson Dr Juliet Wright 